Трончук I. С., доктор сільськогосподарських наук,

Рак Т. М., кандидат сільськогосподарських наук

Полтавська державна аграрна академія

\title{
РІЧНА ПОТРЕБА В ОБМІННІЙ ЕНЕРЇІЇ ТА ПЕРЕТРАВНОМУ ПРОТЕЇНІ КОРІВ ІЗ НАДОЯМИ МОЛОКА ВІД 5000 ДО 9000 кГ
}

Рецензент - доктор сільськогосподарських наук, професор А. А. Поліщук

Узагальнено теоретичні основи і сучасний передовий досвід годівлі високопродуктивних корів. На основі кривих надоїв молока за лактацію визначено добові надої, місячну й річну потребу у поживних речовинах. Річна потреба в обмінній енертї (OE) на корову з надоєм 5000 кг дорівнює 57119 МДж, при 7000 кг - 69430 і при 9000 кг - 84363 МДж; $y$ перетравному протеїні, відповідно, 495,17; 643,68 та 799,35 кг. Уточнено структуру раціонів у відсотках до енергетичної поживності й на основі ичих данних визначено річну потребу в кормах.

Зокрема, річна потреба у концентрованих кормах (комбікормах-концентратах із поживністю 1 кг не менше 10,5 МДж) за надоїв 5000 кг молока дорівнює 14,17 и, при 7000 кг - 21,24 і при 9000 кг$31,31 u$.

Ключові слова: корови, молоко, обмінна енергія, протеїн, структура рачіонів, корми.

Постановка проблеми. Нині актуальною проблемою в Україні є підвищення річних надоїв молока на корову до 5000-6000 кг, а в передових господарствах - близько 7000-9000 кг. Цього можна досягати передусім за рахунок поглиблення селекційної роботи (від якої залежить до $50 \%$ продуктивності корів), удосконаленням кормової бази, впровадженням повноцінної годівлі й найбільш сучасних прогресивних технологій виробництва молока.

На сьогодні в Україні користуємося нормами годівлі, прийнятими у 1985 році за продуктивності корів від 2500 до 6000 кг. Зокрема річна потреба в ОЕ, відповідно, знаходиться в межах від 37,5 до 69,0 тис. МДж (31,25-60,00 ц. корм. од.), перетравного протеїну - від 297 до 660 кг [1]. Проте зараз у окремих передових господарствах річні надої молока зросли до 6000-8000 кг. Тому назріла стала проблема визначення потреби таких корів у поживних речовинах, уточнення структури раціонів і річної потреби в кормах.

Аналіз основних досліджень i публікацій, у яких започатковано розв'язання проблеми. У США в 2006 році від 9,043 млн корів середньорічний надій молока становив 9119 кг. Виробництво молока на людину в рік склало 274 кг, тобто одна корова забезпечує молоком 32-х людей. На корову за рік згодовують близько 85000 МДж $\mathrm{OE}, 3$ них концентровані корми у вигляді високопоживних комбікормів-концентратів - близько 51000 МДж, або $60 \%$ за поживністю. Протягом лактації на 1 кг молока використовують до 450 г комбікормів.

Значна увага надається стимуляції рубцевого травлення, використовуючи дріжджові ферментази И-Сак, стимулюючи травлення кормів, СелПлекс (органічний селен), Мікосорб - натуральний адсорбент мікотоксинів [5].

Завдяки такій годівлі й інтенсивній цілеспрямованій селекції у штаті Вісконсія фермер Том Кестер у 2010 році від корови № 1326 за 365 днів третьої лактації одержав 32804 кг молока з вмістом жиру 3,86 \% і білку - 3,12\%. Батько цієї корови (Стоузер Марті-ЕТ 17349614) оцінений по 26144 дочках, від яких у середньому одержано по 11784 кг молока з вмістом жиру 3,6 \% і білку $3,1 \%[14]$.

У племгосподарстві «Пушкінське» Ленінградської області від 700 корів річний надій становив 9035 кг. За рік на корову згодовано кормів загальною поживністю 70,15 ц корм. од., а саме: сіна -10 ц, сінажу - 5 ц, силосу - 60 ц, кормових буряків - 32 ц, зелених кормів - 79 ц, кормової патоки $-4,6$ ц, концентрованих кормів $-34,4$ ц. У структурі раціону за поживністю зелені корми склали $22,5 \%$, грубі та соковиті - 16,1, а концентровані - 61,4\%. На 1 кг молока витрачено 0,78 корм. од., у тому числі 432 г концентрованих кормів [7].

У ВАТ «Чумаки» річний надій на корову досяг 8616 кг за рентабельності молока $112 \%$. Добове споживання кормів склало 20-21 корм. од., із яких концентрованих близько 11 кг, або $56 \%$ за поживністю [4].

Найефективнішими $є$ технології, що грунтуються на безприв'язному утриманні та доїнні корів у автоматизованих доїльних залах. Такі технології впроваджено у ЗАТ «Агро-Регіон», ВАТ «Терезине», ТОВ «Агрофірма Світанок», 
ТОВ «Агросвіт» Київської, Агрофірмі «Маяк» Черкаської, ДП «Артеміда» Вінницької, «Екопрод» Донецької областей [3].

Iз них найбільш прогресивними $€ з$ чотирма цехами: роздою та осіменіння, виробництво молока, сухостійних тільних корів, родильний із профілакторієм для телят. За такої системи у період роздою концентровані корми згодовують у складі кормових мішанок (50 \%) та індивідуально 3 автоматизованих кормових станцій (50 \%). Порівняно з використанням усіх кормів у суміші молочна продуктивність корів підвищувалася на $6,4 \%$ [6]. У період роздою доцільно застосовувати трьохразове доїння корів [11].

За всіх технологій у зимовий період необхідно контролювати в раціонах вміст цукрів, органічних кислот i сирої клітковини. Фізіологічно нормальною кількістю цукрів у сухій речовині $€$ $10 \%$, органічних кислот - близько $3 \%$, сирої клітковини - $18 \%$. Це дає можливість забезпечити $\mathrm{pH}$ кормової маси у рубці на рівні 6-6,5, оптимальне співвідношення молочної та оцтової кислот, що гарантує нормальну життєдіяльність мікроорганізмів, високу перетравність кормів, попереджує ацидоз [12, 13].

Мета досліджень і методика їх проведення. Мета досліджень - визначити річну потребу в обмінній енергії, поживних речовинах і кормах для корів із високою продуктивністю в умовах кормової бази України. В основу їх визначення взято лактаційні криві надоїв молока корів із живою масою 600 кг на 5000 і 7000 кг та 700 кг на 9000 кг (див. рис.). На основі їх визначили середньодобові надої молока по кожному з 10 місяців лактації та поживність, структуру і склад раціонів. Складаючи раціони, обмежувалися вмістом у них сирої клітковини в кількості 4500 г, згідно 3 діючими нормами. Для двох останніх місяців тільності корів використано існуючі нормативи годівлі [1].

За сумою потреби для дійних і сухостійних тільних корів визначили річну потребу в обмінній енергії та перетравному протеїні. На основі узагальнення літературних даних уточнили структуру раціонів $[4,7]$ і річну потребу в кормax.

Результати досліджень. Лактаційні криві корів iз річними надоями молока 5000, 7000 і 9000 кг представлено на рис. 1. У них сервіс-період прийнято за 75 днів. На основі цих даних визначили добові та місячні надої молока корів різної продуктивності (табл. 1).

Із даних таблиці видно, що за річного надою молока 5000 кг у перші три місяці він зростає від 13 до 23 кг і далі поступово, протягом семи місяців, зменшується до 7 кг; за річного надою 7000 кг у перші чотири місяці підвищується із 17 до 32 кг і далі зменшується до 8 кг; за річного надою 9000 у перші чотири місяці підвищується від 20 до 42 кг, зменшуючись у кінці лактації до 10 кг.

На основі цих надоїв, користуючись існуючими нормами годівлі, спочатку визначили добову потребу в обмінній енергії та перетравному протеїні, а потім - місячну. Ці дані доповнили потребою у них для сухостійних тільних корів в останніх два місяці тільності й визначили річну потребу (табл. 2).

Встановлено, що для корів із надоєм 5000 кг потреба в ОЕ дорівнює 57119 МДж, із 7000 кг 69430 та 9000 кг - 84363 МДж, потреба у перетравному протеїні 495,15, 643,68 і 799,35 кг відповідно.

Згідно $з$ цими даними, визначена вона і для корів із річним надоєм 6000 і 8000 кг молока, а саме: обмінна енергія, відповідно, 63414 та 76973 МДж, перетравний протеїн - 571,0 i 727,3 кг.

1. Помісячні та середньодобові надої молока за лактацію, кг (місяць, день)

\begin{tabular}{|c|c|c|c|c|c|c|c|c|c|c|c|}
\hline \multicolumn{10}{|c|}{ Місяці лактації } & Усього \\
\hline 1 & 2 & 3 & 4 & 5 & 6 & 7 & 8 & 9 & 10 & за лактацію \\
\hline \multicolumn{10}{|c|}{ За річного надою 5000 кг } \\
\hline 510 & 682 & 690 & 682 & 585 & 527 & 450 & 403 & 300 & 217 & 5046 \\
\hline 17 & 22 & 23 & 22 & 19,5 & 17 & 15 & 13 & 10 & 7 & - \\
\hline \multicolumn{10}{|c|}{ За річного надою 7000 кг } \\
\hline 630 & 868 & 945 & 992 & 870 & 806 & 675 & 540 & 420 & 279 & 7025 \\
\hline 21 & 28 & 31,5 & 32 & 29 & 26 & 22,5 & 18 & 14 & 9 & - \\
\hline \multicolumn{10}{|c|}{ За річного надою 9000 кг } \\
\hline 750 & 1054 & 1200 & 1302 & 1155 & 1070 & 900 & 713 & 525 & 372 & 9041 \\
\hline 25 & 34 & 40 & 42 & 38 & 34,5 & 30 & 23 & 17,5 & 12 & - \\
\hline
\end{tabular}




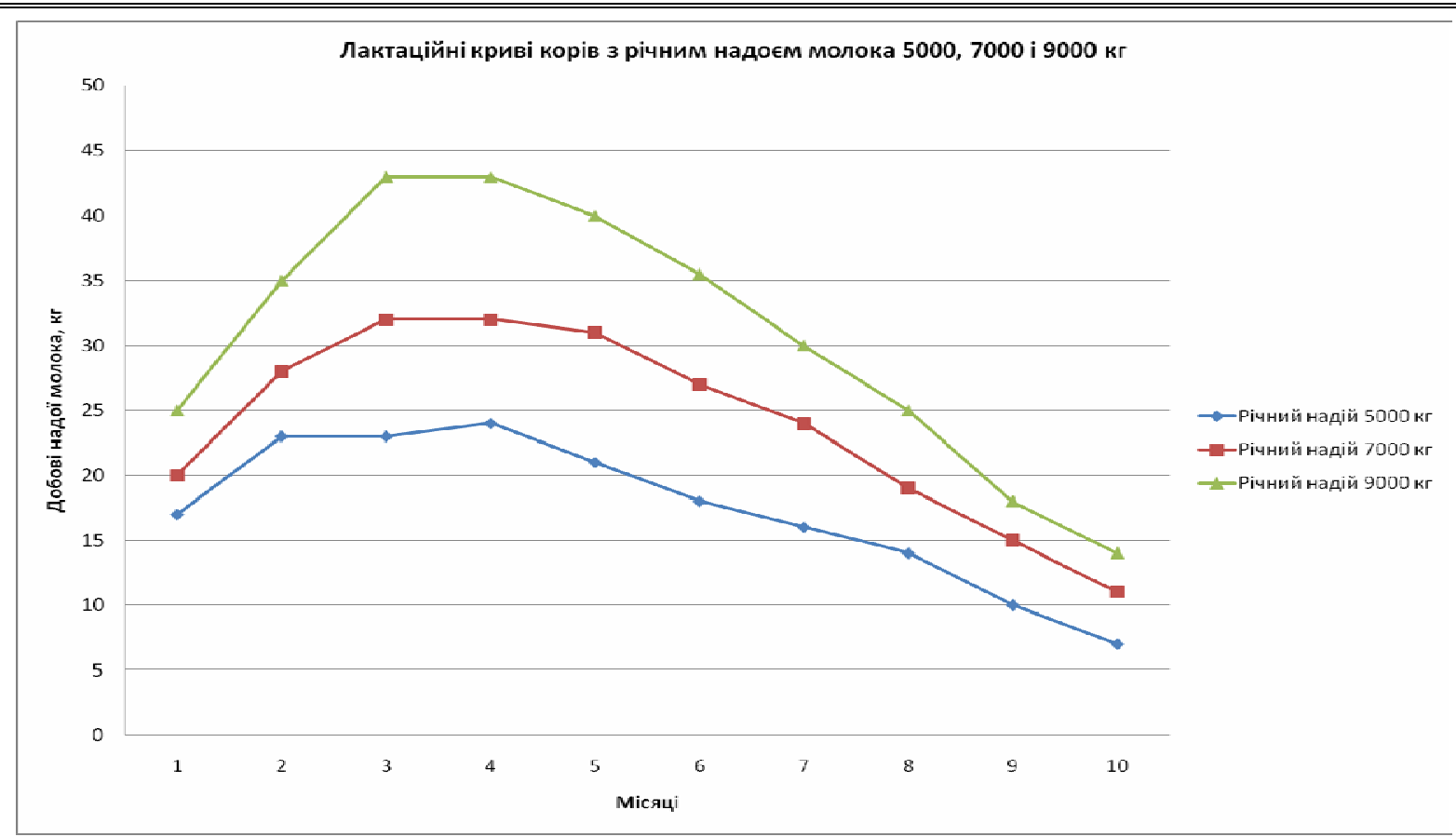

Рис. Лактаційні криві корів із річними надоями молока 5000, 7000 і 9000 к2

2. Річна потреба корів в обмінній енертії та перетравному протеїні

\begin{tabular}{|c|c|c|c|c|c|c|c|c|c|c|c|c|}
\hline \multirow{2}{*}{ Показник } & \multicolumn{10}{|c|}{ Місяці лактації } & \multirow{2}{*}{\begin{tabular}{|c|} 
Сухо- \\
стійний \\
період
\end{tabular}} & \multirow[b]{2}{*}{ Разом } \\
\hline & 1 & 2 & 3 & 4 & 5 & 6 & 7 & 8 & 9 & 10 & & \\
\hline \multicolumn{13}{|c|}{ Річний надій молока 5000 кг } \\
\hline $\begin{array}{c}\text { Добова потреба: } \\
\text { ОЕ, МДж }\end{array}$ & 161 & 189 & 194 & 189 & 177 & 161 & 151 & 140 & 135 & 130 & 125 & - \\
\hline $\begin{array}{c}\text { Перетравний } \\
\text { протеїн, г }\end{array}$ & 1360 & 1665 & 1745 & 1665 & 1510 & 1360 & 1260 & 1160 & 1120 & 1080 & 1175 & - \\
\hline \multicolumn{13}{|l|}{ Місячна потреба: } \\
\hline ОЕ, МДж & 4830 & 5859 & 5820 & 5859 & 5310 & 4991 & 4530 & 4340 & 4050 & 4030 & 7500 & 57119 \\
\hline $\begin{array}{c}\text { Перетравний } \\
\text { протеїн, кг }\end{array}$ & 40,80 & 51,61 & 52,35 & 51,61 & 45,30 & 42,16 & 37,80 & 35,96 & 33,60 & 33,48 & 70,50 & 495,17 \\
\hline \multicolumn{13}{|c|}{ Річний надій молока 7000 кг } \\
\hline $\begin{array}{c}\text { Добова потреба: } \\
\text { OE, МДж }\end{array}$ & 183 & 225 & 245 & 249 & 231 & 213 & 193 & 166 & 146 & 132 & 153 & - \\
\hline $\begin{array}{c}\text { Перетравний } \\
\text { протеїн, г }\end{array}$ & 1587 & 2090 & 2439 & 2475 & 2217 & 1960 & 1703 & 1410 & 1210 & 1095 & 1485 & - \\
\hline \multicolumn{13}{|l|}{ Місячна потреба: } \\
\hline OE, МДж & 5490 & 6750 & 7350 & 7719 & 6930 & 6603 & 5790 & 5146 & 4380 & 4092 & 9180 & 69430 \\
\hline $\begin{array}{c}\text { Перетравний } \\
\text { протеїн, кг }\end{array}$ & 47,61 & 64,79 & 73,14 & 76,72 & 66,51 & 60,76 & 51,09 & 43,71 & 36,30 & 33,95 & 89,10 & 643,68 \\
\hline \multicolumn{13}{|c|}{ Річний надій молока 9000 кг } \\
\hline $\begin{array}{c}\text { Добова потреба: } \\
\text { OE, МДж }\end{array}$ & 214 & 269 & 304 & 319 & 292 & 269 & 245 & 203 & 174 & 143 & 170 & - \\
\hline $\begin{array}{c}\text { Перетравний } \\
\text { протеїн, г }\end{array}$ & 1912 & 2637 & 3065 & 3217 & 2922 & 2637 & 2300 & 1765 & 1430 & 1130 & 1625 & - \\
\hline \multicolumn{13}{|l|}{ Місячна потреба: } \\
\hline OE, МДж & 6420 & 8339 & 9120 & 9889 & 8760 & 8339 & 7350 & 6293 & 5220 & 4433 & 10200 & 84363 \\
\hline $\begin{array}{c}\text { Перетравний } \\
\text { протеїн, кг }\end{array}$ & 57,36 & 81,75 & 91,95 & 99,73 & 87,66 & 81,75 & 69,00 & 54,72 & 42,90 & 35,03 & 97,50 & 799,35 \\
\hline
\end{tabular}


СІЛЬСЬКЕ ГОСПОДАРСТВО. ТВАРИННИЦТВО

\section{3. Структура раціонів для високопродуктивних корів, \% за енергетичною поживністю}

\begin{tabular}{|c|c|c|c|c|c|c|c|}
\hline \multirow[b]{2}{*}{$\begin{array}{l}\text { Добовий } \\
\text { надій, кг }\end{array}$} & \multirow{2}{*}{$\mid \begin{array}{c}\text { Концент- } \\
\text { рація ОЕ в } \\
1 \text { кг сухої } \\
\text { речовини, } \\
\text { МДж }\end{array}$} & \multicolumn{2}{|c|}{ Структура раціонів, \% } & \multirow[b]{2}{*}{$\begin{array}{l}\text { Добовий } \\
\text { надій, кг }\end{array}$} & \multirow{2}{*}{$\begin{array}{c}\text { Концен- } \\
\text { трація ОЕ } \\
\text { в } 1 \text { кг су- } \\
\text { хої речо- } \\
\text { вини, } \\
\text { МДж }\end{array}$} & \multicolumn{2}{|c|}{$\begin{array}{c}\text { Структура раціонів, } \\
\%\end{array}$} \\
\hline & & $\begin{array}{c}\text { грубі, соковиті } \\
\text { і зелені корми }\end{array}$ & $\begin{array}{c}\text { концентровані } \\
\text { корми }\end{array}$ & & & $\begin{array}{c}\text { грубі, } \\
\text { соковиті } \\
\text { й зелені } \\
\text { корми }\end{array}$ & $\begin{array}{c}\text { кон- } \\
\text { центрова- } \\
\text { ні корми }\end{array}$ \\
\hline 10 & 8,71 & 84,0 & 16,0 & 31 & 10,44 & 60,2 & 39,8 \\
\hline 13 & 8,81 & 80,6 & 19,4 & 34 & 10,70 & 56,8 & 43,2 \\
\hline 16 & 8,91 & 77,2 & 22,8 & 37 & 10,95 & 53,4 & 46,6 \\
\hline 19 & 9,25 & 73,8 & 26,2 & 40 & 11,21 & 50,0 & 50,0 \\
\hline 22 & 9,59 & 70,4 & 29,6 & 43 & 11,47 & 46,6 & 53,4 \\
\hline 25 & 9,90 & 67,0 & 33,0 & 46 & 11,73 & 43,2 & 56,8 \\
\hline 28 & 10,18 & 63,6 & 36,4 & 49 & 12,00 & 39,8 & 60,2 \\
\hline
\end{tabular}

4. Річна потреба у концентрованих кормах

\begin{tabular}{|c|c|c|c|c|c|c|c|c|c|c|c|c|}
\hline \multirow[b]{2}{*}{ Показник } & \multicolumn{10}{|c|}{ Місяці лактації } & \multirow{2}{*}{$\begin{array}{c}\text { Сухо- } \\
\text { стій- } \\
\text { ний } \\
\text { період }\end{array}$} & \multirow[b]{2}{*}{$\begin{array}{c}\text { Усьо- } \\
\text { го }\end{array}$} \\
\hline & 1 & 2 & 3 & 4 & 5 & 6 & 7 & 8 & 9 & 10 & & \\
\hline \multicolumn{13}{|c|}{ Річний надій 5000 кг } \\
\hline Концк & 24 & $\overline{9,6}$ & 30,7 & 29,6 & 27,0 & 24,0 & 21,7 & 19,4 & 6,0 & 15,0 & 30,0 & 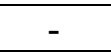 \\
\hline OE, $\mathrm{I}$ & 1159 & 1734 & 1787 & 1734 & 1434 & 1198 & 983 & 841 & 648 & 605 & 2750 & 14843 \\
\hline Комбікорми, ц & 1,10 & 1,65 & 1,70 & 1,65 & 1,37 & 1,14 & 0,94 & 0,80 & 0,62 & 0,58 & 2,62 & 14,17 \\
\hline \multicolumn{13}{|c|}{ Річний надій 7000 кг } \\
\hline Конци & 28,5 & 36,4 & 40,3 & 40,9 & 37,6 & 34,1 & 30,1 & 25,1 & 20,6 & 16,0 & 29,0 & - \\
\hline $\mathrm{OE}$, & 1565 & 2457 & 2962 & 3157 & 2606 & 2252 & 1743 & 1292 & 985 & 655 & 2662 & 22336 \\
\hline Комбік & 1,49 & 2,34 & 2,82 & 3,01 & 2,48 & 2,14 & 1,66 & 1,23 & 0,94 & 0,62 & 2,54 & 21,24 \\
\hline \multicolumn{13}{|c|}{ Річний надій 9000 кг } \\
\hline Конц & 33,0 & 43,2 & 50,0 & 52,3 & 47,7 & 43,2 & 38,7 & 30,7 & 22,8 & 18,4 & 28 & - \\
\hline OE, $\mathrm{N}$ & 2119 & 3602 & 4560 & 5172 & 4179 & 3602 & 2844 & 1932 & 1190 & 816 & 2856 & 32872 \\
\hline Комбікорми, ц & 2,02 & 3,43 & 4,34 & 4,93 & 3,98 & 3,43 & 2,71 & 1,84 & 1,13 & 0,78 & 2,72 & 31,31 \\
\hline
\end{tabular}

Слід зазначити, що наші дані потреби корів із річним надоєм молока 9000 кг співпадають із фактичними показниками племзаводу «Пушкінське», де на корову було витрачено 70,15 ц корм. од., або 80000 МДж ОЕ.

3 урахуванням досвіду кращих господарств $[4,7]$ уточнили також структуру раціонів (табл. 3). У ній показано, що з підвищенням добових надоїв від 10 до 49 кг концентрація обмінної енергії в 1 кг сухої речовини раціонів збільшується від 8,71 до 12,0 МДж, або на $38 \%$. При цьому вміст сирої клітковини зменшується від 27 до $18 \%$, що й дає можливість збільшувати добове споживання обмінної енергії кормів від 135 до 350 МДж, або у 2,6 разу більше $[9,10]$.

Виходячи 3 такої структури раціонів, ми визначили потребу у концентрованих кормах із розрахунку на комбікорми-концентрати поживність 1 кг не менше 10,5 МДж. Проведені розрахунки показали, що річна потреба у них за надо- їв 5000 кг становить 14,17 ц, 6000 кг - 17,70, 7000 кг - 21,24, 8000 кг - 26,27 і 9000 кг - 31,31 ц (табл. 4).

Прогнозування річної потреби в інших кормах залежить від конкретної технології виробництва кормів у господарстві та використання їх у зимовий і літній періоди. Доцільно рекомендувати на зимовий період кукурудзяний силос (як основний $i$ найдешевший корм) у кількості 60 ц та оптимальну потребу у сіні - 10 ц на корову.

\section{Висновки:}

1. Річна потреба в обмінній енергії для корів із надоєм молока від 5000 до 9000 кг збільшується від 57119 до 84363 МДж (на 47 \%), у перетравному протеїні - від 495,17 до 799,35 кг (на $61,4 \%)$.

2. Структура раціонів залежить від добового надою, а саме: за добового надою 10 кг грубі, соковиті й зелені корми за енергетичною поживністю складають 84 \%, концентровані корми - 
$16 \%$, при 50 кг, відповідно, 38,7 і 61,3 \% (на кожних 3 кг молока $+3,4 \%$ ).

3. Оптимальна потреба корови на 212 днів зимового стійлового періоду в кукурудзяному силосі дорівнює 60 ц, у сіні - 10 ц. Річна потреба у концентрова-

\section{БІБЛІОГРАФІЯ}

1. Калашников А. П., Клейменов Н. И. Нормы и рационы кормления сельскохозяйственных животных. Справочное пособие. - М. : Агропромиздат. $-1985 .-350 \mathrm{c}$.

2. Кравцов Е., Кукла Л. Молока і м'яса можна виробляти більше // Тваринництво України. - К., 2006. - № 5. - С. 5-7.

3. Кудлай І., Гончарук О., Артеменко Н. Виробництво молока у племзаводі «Терезине» // Тваринництво України. - К., 2007. - №2. - С. 82-83. 4. Литвиненко Н., Колот І., Гламазда В. [та інmi]. Як добитись високих надоїв // Тваринництво України. - К., 2004. - №9. - С. 2-3.

5. Молочний форум Global Dairy 500 // Молочное и мясное скотоводство. - М., 2010. - №8. C. 22-23.

6. Попков Н. А., Трофимов А. Ф., Тимоменко В. Н. [u $\partial p$.]. Усовершенствованные технологии содержания коров в период раздоя на фермах с интенсивным производством молока // Ефективне тваринництво. - К., 2010. - №8. - С. 16-21.

7. Симонов Г. А., Сабурин В. А., Коваль Ю. В. [u $\partial p$.$] . Опыт создания высокопродуктивных мо-$ лочных стад // Зоотехния. - М., 2005. - № 1. C. $11-15$.

8. Славов В., Фурса М., Кутова Г. Кормові ресурси - економічна основа конкурентоспроможного тваринництва // Тваринництво України. - них кормах у вигляді комбікормів-концентратів із поживністю 1 кг не менше 10,5 МДж ОЕ за надою 5000 кг становить 14,17 ц, 6000 кг - 17,70 ц, 7000 кг - 21,24 ц, 8000 кг - 26,27 ц і 9000 кг 31,31 ц.

К., 2008. - №9. - C. 28-29.

9. Трончук I. С., Бердник I. Ю. Вплив концентрації обмінної енергії та поживних речовин у сухій речовині раціонів на продуктивність дійних корів // Вісник Полтавської державної аграрної академії. - 2006. - № 2. - С. 86-90.

10. Трончук I. С., Рак Т. М., Чижсанська Н. В. Структура і поживність раціонів для дійних корів із річним надоєм молока від 6 до 9 тисяч кілограмів // Вісник Полтавської державної аграрної академії. - 2012. - №1. - С. 107-111.

11. Хольгер Брюкнер. Поиск оптимальной кратности доения // Ефективне тваринництво. - К., 2010. - № 1. - C. 26-27.

12. Цюпко В. В., Проніна В. В. Вплив окремих чинників годівлі на відтворювальну функцію корів // Науково-технічний бюлетень інституту тваринництва УААН. - Х., 2008. - №96. C. 445-449.

13. Шалатонов И. С. Нарушение рубцового пищеварения у высокопродуктивных коров при силосно-сенажно-концентратном типе кормления // Зоотехния. - М., 2005. - № 4. - С. 12-13.

14. Янчуков Я., Матвеева Е., Лаврухина А. Горизонты в селекции молочного скота // Молочное и мясное скотоводство. - М., 2011. - №1. - С. 1011. 